\title{
MANAJEMEN PERILAKU BIROKRASI TERHADAP PENINGKATAN PELAYANAN PUBLIK DI KANTOR DESA BULO WATTANG KECAMATAN PANCA RIJANG KABUPATEN SEDENRENG RAPPANG
}

\author{
1)Supriyadi Kahar, 2)Muhammad Rusdi, 3)Abdul Jabbar \\ Fakultas IImu Sosial dan IImu Politik Universitas Muhammadiyah Sidenreng Rappang \\ supriyadi43161040@gmail.com
}

\begin{abstract}
Abstrak
Penelitian ini bertujuan untuk mengetahui Manajemen Perilaku Birokrasi di kantor Desa Bulo Wattang, Pelayanan publik di kantor Desa Bulo Wattang dan untuk mengetahui manajemen perilaku birokrasi terhadap peningkatan pelayanan publik di kantor Desa Bulo Wattang Kecamatan Panca Rijang Kabupaten Sidenreng Rappang. Popolasi dalam penelitian ini adalah 337 Kepala Keluarga yang dimana pengambilan sampel yang digunakan yaitu Probability Sampling, dengan teknik sampling acak/random sampling dengan menggunakan Rumus Yount 10\% dengan jumlah sampel 34 Kepala Keluarga, Penelitian ini menggunakan Metode Deskritif Kuantitatif. Teknik Pengumpulan data yang digunakan melalui Observasi, Wawancara Kuisioner, dan Study Kepustakaan. Teknik Analisis data yang digunakan adalah analisis tabulasi frekuensi, dan analisis regresi linear dengan menggunakan SPSS 16 for Windows. Hasil penelitian ini menujukkan bahwa rata-rata persentase Manajemen perilaku birokrasi di kantor Desa Bulo Wattang Kecamatan Panca Rijang Kabupaten Sidenreng Rappang sebesar 65,8\% dengan kategori baik, pelayanan publik di kantor Desa Bulo Wattang Kecamatan Panca Rijang Kabupaten Sidenreng Rappang sebesar $60,32 \%$ dengan kategori cukup baik manajemen perilaku birokrasi terhadap peningkatan pelayanan publik di kantor Desa Bulo Wattang Kecamatan Panca Rijang Kabupaten Sidenreng Rappang sebesar 33,0\% dengan kategori berpengaruh.
\end{abstract}

Kata Kunci : Manajemen Pelayanan publik

\begin{abstract}
This study aims to determine the management of bureaucratic behavior at the Bulo Wattang Village office, public services at the Bulo Wattang Village office and to determine the management of bureaucratic behavior towards improving public services at the Bulo Wattang Village office in Panca Rijang District, Sidenreng Rappang Regency. The population in this study was 337 heads of households where the sampling used was Probability Sampling, with a random sampling technique using the 10\% Yount Formula with a total sample of 34 heads of households. This study used a Quantitative Descriptive Method. Data collection techniques used through observation, questionnaires, and documentation. The data analysis technique used is frequency tabulation analysis, and linear regression analysis using SPSS 16 for Windows. The results of this study show that the average percentage of bureaucratic behavior management in the office of Bulo Wattang Village, Panca Rijang District, Sidenreng Rappang Regency is $65.8 \%$ with a good category, public services at the Bulo Wattang Village office, Panca Rijang District, Sidenreng Rappang District are $60.32 \%$ with a fairly good category of bureaucratic behavior management to improve public services in the office of the Village of Bulo Wattang, District of Panca Rijang, District of Sidenreng Rappang by 33.0\% with an influence category.
\end{abstract}

Keywords: Management of public services

PRAJA | Volume 7 | Nomor 2 | Edisi Juni 2019 


\section{A. PENDAHULUAN}

Undang-undang Noomor 6 Tahun 2014 Tentang Desa dan adat atau biasa disebut dengan nama lainnya, selanjutnya disebut desa adalah kesatuan masyarakat hukum yang memiliki batas wilayah yang berwenangan untuk mengatur dan mengurus urusan pemerintahan, kepentingan masyarakat setempat berdasarkan prakarsa masyarakat, hak asal usul dan atau hak tradisional yang diakui dan dihormati dalam sistem pemerintahan Negara Republik Indonesia. Negara Republik Indonesia yang berdasarkan dengan Pemerintahan daerah. Pemerintah dalam melaksanakan tugas pokok dan fungsinya menggunakan birokrasi sebagai alat menjalankan kegiatan pemerintahan yang dilakukan oleh aparatur pemerintah untuk mewujudkan fungsi aparatur sebagai abdi masyarakat disamping sebagai abdi negara.(Eka Putra, 2016)

Pemerintah daerah sedang dalam proses penyempurnaan, terutama dalam memberikan pelayanan pada masyarakat. (Sedarmayanti, 2009) menyatakan bahwa pelayanan yang berkualitas itu harus memiliki 5dimensiyaitu:Realibility (handal), responsive ness (pertanggungjawaban), assurane (jamin an) empaty (empati). Pemerintah desa atau yang disebut dengan nama lain adalah Kepala Desa dan Perangkat Desa sebagai unsur penyelenggara pemerintahan desa. Dari penegasan peraturan-undangan jelas bahwa Desa merupakan unit Pemerintah terendah yang di akui dalam system penyelenggaraan pemerintahan nasional. Ini dapat berarti bahwa Pemerintah Desa merupakan organisasi Pemerintah Desa yang di tuntut untuk meningkatkan Manajemen birokrasi di dalam Penyelenggaraan Pelayanan Publik Sesuai dengan harapan masyarakat.

Berkaitan dengan ketentuan tersebut, hal ini mengisyaratkan bahwa dalam meleksanakan urusan rumah tangga desa, melakukan pembinaan, pembangunan masyarakat, dan membina perekonomian desa harus dapat dijalangkan oleh Manajemen birokrasi desa yang baik karna masyarakat desa telah berkembang dengan berbagai kegiatan yang semakin membutuhkan Pelayanan Pemerintah yang profesional. Berdasarkan observasi awal yang dilakukan oleh, dengan beberapa masyarakat serta salah satu tokoh masyarakat di Desa Bulo Wattang, Kecamatan Panca Rijang Kabupaten Sidenreng Rappang masalah yang dijumpai calon peneliti yaitu:

1. Manajemen birokrasi dan pelayanan yang diberikan oleh aparat birokrasi pemerintah Desa Bulo Wattang Kecamatan Panca Rijang Kabupaten Sidenreng Rappang belum memuaskan pelanggan/masyarakat, khususnya pelayanan dalam pembuatan suratmenyurat serta persoalan-persoalan dimasyarakat terkadang lama dan berbelit-belit.

2. Didapatkan juga bahwa di dalam aparat birokrat desa terkadang terlambat datang dan bahkan pulang lebih awal dari waktu yang telah ditetapkan, hal ini terlihat ketika masyarakat datang berurusan ke kantor desa dan kemudian para aparat birokrasi desa yang justru belum datang di kantor desa. hal ini tentunya melanggar tata tertib desa yang ada, sesuai dengan peraturan Bupati Sidenreng Rappang Nomor 23 Tahun 2017 Tentang Jam Kerja Aparatur Sipil Kabupaten Sidenreng Rappang Pasal 4 dimana ketentuan jam kerja sebagaimana yang dimaksud pada pasal 3 yaitu hari senin-kamis pukul 08.00 wita s/d 16.30 wita. Hari jumat pukul 08.00 wita s/d 17.00. yang semestinya datang paling lambat jam 08:00.

3. Selain itu para aparat desa tidak terlalu melayani dan memperhatikan jika ada masyarakat yang datang ke Kantor Desa Bulo Wattang dan hanya kebanyakan/sibuk memainkan gejetnya. Keluhan tersebut di peroleh dari salah satu warga desa Bulo Wattang yang hendak mengurus surat-surat keterangan di kantor desa, tetapi tidak bisa di layani dengan baik. Produktivitas layanan yaitu efesiensi dan efektivitas layanan publik ini belum bisa di capai, demikian pula dengan hasil capaian kerja birokrasi dalam menyelenggarakan pelayanan publik khususnya masyarakat Desa Bulo Wattang Kecamatan Panca Rijang Kabupaten Sidenreng Rappang yang menjadi kewenangan desa belum sepenuhnya maksimal dilaksanakan.

4. Manajemen Birokrasi Aparatur pemerintah desa juga seringkali masih bingung dengan cara pengoprasian computer sehingga waktu penyelesaiannya dalam memberikan 
layanan kepada pelanggan/masyarakat tidak menentu.

Berdasarkan uraian di atas, maka penulis tertarik untuk mengadakan penelitian dengan judul Manajemen Perilaku Birokrasi Terhadap Peningkatan Pelayanan Publik di Desa Bulo Wattang Kecamatan Panca Rijang Kabupaten Sidenreng Rappang dengan tujuan untuk mengetahui Manajemen Perilaku Birokrasi di Desa Bulo Wattang, Kecamatan Panca Rijang Kabupaten Sidenreng Rappang, untuk mengetahui bagaimana Pelayanan Publik di Desa Bulo Wattang, Kecamatan Panca Rijang Kabupaten Sidenreng Rappang, dan untuk mengetahui manajemen perilaku birokrasi terhadap peningkatan Pelayanan Publik di Desa Bulo Wattang, Kecamatan Panca Rijang Kabupaten Sidenreng Rappang.

Shafritz dan Runssel (1997:20) dalam Harbani Pasolong (2014:82) Manajemen adalah berkenaan dengan orang yang bertanggung jawab menjalangkan suatu organisasi, dan proses menjalangkan organisasi itu sendiri yaitu pemanfaataan sumber daya seperti orang dan mesin untuk mencapai tujuan organisasi, Hal ini berarti bahwa manajemen meliputi: pengetahuan tentang apa yang harus mereka lakukan, menetapkan dan memahami cara melakukannya, serta mengukur efektivitas usaha mereka. (Zainuddin, 2017).

Manajemen dan organisasi merupakan dua sisi mata uang yang tak terpisahkan. Keberadaan organisasi merupakan wadah bagi manajemen, tetapi manajemen pula yang menentukan gerak dan napas organisasi. Artinya organisasi tidak dapat digerakkan tanpa manajemen dan sebaliknya manajemen hanya dapat diimplementasikan dalam organisasi. Koontz dalam (Zainuddin, 2017) memusatkan perhatiannya pada aspek hubungan antara manajemen dengan pencapaian suatu tujuan yang menekankan pada usaha memanfaatkan orang-orang lain dengan pencapaiaan suatu tujuan. Oleh karna itu orang-orang di dalam organisasi harus mempunyai wewenang tugas dan tanggung jawabnya yang jelas. Perspektif yang di kemukakan oleh westra dalam (Zainuddin, 2017) bahwa manajemen sebagai penggerakan, pengorganisasian, dan pengarahan usaha manusia untuk memanfaatkan secara efektif material dan fasilitas untuk mencapai suatu tujuan, seperti: orang, uang, materi, mesin, metode, dan waktu dan prasarana lainnya.

Merujuk pada ketiga pandangan tersebut, siagian (Zainuddin,2017) menyimpulkan bahwa manajemen merupakan inti dari administrasi karna manajemen merupakan alat pelaksana dari administrasi. Unsur-unsur yang ada dalam manajemen tersebut apabila dijabarkan dalam penjelasan adalah Perencanaan, Pengorganisasian, Penggerakan, dan Pengawasan.

Sampara Lukman yang dikutip oleh Lijan Sinambela, pelayanan adalah suatu kegiatan atau urutan kegiatan yang terjadi dalam interaksi langsung antar seseorang dengan orang lain atau mesin secara fisik, dan menyediakan kepuasaan pelanggan. Sementara dalam Kamus Besar Bahasa Indonesia dijelaskan pelayanan sebagai hal, cara, atau hasil pekerjaan melayani (Lijan Poltak S, 2006:5). Dalam (Juliette, 2015). Menurut Zeithhaml dkk dalam (Pasolong, Teori Administrasi Publik, 2011) ada lima indikator untuk mengatahui kualitas pelayanan yang dirasakan secara nyata olek konsumen yaitu

1. Bukti fisik (tangibles) yaitu penyedia layanan harus menyediakan fasilitas baik fisik maupun nono fisik. Pemenuhan kebutuhan dalam pelayanan publik seharusnya ditangani oleh tenaga ahli sehingga pelayanan yang di berikan benar-benar memberikan pemenuhan terhadap apa yang dibutuhkan oleh pengguna layanan (Sinambela, 2014).

2. Keandalan (Reability) yaitu Menurut (Sinambela, 2014) keandalan adalah kemampuan memberikan pelayanan dengan segera dan memuaskan.

3. Daya tanggap (Resvonsiviness) yaitu kesanggupan untuk membantu dan menyediakan pelayanan secara cepat dan tepat, serta tanggap terhadap keiginan konsumen. Keiginan melayani konsumen secara tepat. Memberikan pelayanan kepada konsumen dengan tidak mengulurngulur waktu. Saat pengguna layanan membutuhkan pelayanan maka penyedia layanan segera memberikan layanan tanpa harus menunggu lama.(Sinambela, 2014).

4. Jaminan (Assurance) adalah kemampuan dan keramahan serta sopan santun pegawai dalam meyakinkan kepercayaan konsumen. Tingkat perhatian terhadap 
etika dan moral dalam pemberian pelayanan. Saat memberikan layanan, pelayanan publik harus menunjukkan sikap penghargaan kepada pengguna layanan. Pelayanan yang diberikan memberikan penilaian bagi publik bahwa mereka sangat dihargai karna pelayanan publikmenunjukkan sikap yang ramah dan bersahabat. Mencakup sikap dapat di percaya yang dimiliki para staf (Sinambela, 2014).

5. Empati (Empathy) adalah sikap tegas dan penuh perhatian dari pegawai terhadap konsumen. Tingkat kemauan untuk mengetahui keiginan dan kebutuhan masyarakat. Pelayanan publik harus mengetahui apa dan bagaimana pelayanan yang dibutuhkan oleh masyarakat sehingga dalam pemenuhan pelayanan publik tidak terjadi kesalahan yang berakibat ketidakpuasan terhadap pelayanan publik yang diberikan atau dapat dikatakan agar layanan yang diberikan itu tepat sasaran (Sinambela, 2014).

\section{B. METODE PENELITIAN}

Pendekatan Metode Penelitian ini mengunakan jenis deskriptif kuantitatif, dengan metode ini diharapkan dapat memberikan gambaran secara cermat, jelas dan objektif mengenai masalah yang sedang diteliti.Sedangkan dasarnya adalah survei dimana kegaiatan penelitian menggunakan kuisioner/wawancara sebagai instrument utama dalam pengumpulan data dilapangan. Populasi dalam penelitian ini adalah berjumlah 34 orang/kepala keluarga Dengan menggunakan teknik sampling. Teknik pengumpulan data yang digunakan yaitu melalui observasi, wawancara, kuesioner, dan studi kepustakaan, sedangkan teknik analisis data menggunakan statistik deskriptif dengan bantuan SPSS.

\section{HASIL DAN PEMBAHASAN}

Hasil dari presentase tabel $65.2 \%$ dilihat dari presentase maka dapat dikategorikan "baik" manajemen dinilai dari perencanaan setiap pekerjaan yang akan dilakukan pengambilan keputusan melalu rapat atau diputuskan sendiri oleh desa. Peran Mempengaruhi Bawahan Kemampuan seorang pemimpin dalam mempengaruhi bawahannya, sehingga mau bekerja sama dalam melaksanakan atau merealisasikan
p-ISSN 2302-6960

e-ISSN 2716-165X

suatu program kerja. Adapun indikator presentase tabel $66.4 \%$ melihat rata-rata nilai maka dapat dikategorikan "baik" manajemen dinilai dari pengaruhnya dalam mengorganisasika setiap pekerjaan yang akan dilakukan. Presentase hasil dari tabel $66,4 \%$ dilihat maka dapat dikategorikan "baik" kepemimpinan dinilai dari memberikan hadiah atau sanksi kepada aparat ataupun tidak memuaskan kepada masyarakat. Hasil tabel presentase tabel menunjukkan $65.2 \%$ dilihat dari presentase maka dapat dikategorikan " baik" kepemimpinan dinilai dari sikap keramahannya.

Hasil dari presentase tabel yaitu $54.0 \%$ dilihat dari presentase maka dikategorikan "Cukup Baik" kualitas pelayanan publik dinilai tentang perlengkapan dan tempat pemberian pelayanan yang ada di Kelurahan Lalebata sudah baik. Hasil dari tabel frekuensi yaitu $55.2 \%$ dilihat dari presentase maka dapat dikategorikan "Cukup Baik" kualitas pelayanan publik dinilai dari sikap aparatur dan ketepatan waktu dalam memberikan pelayanan. Hasil tabel yaitu menunjukkan $61.0 \%$ dilihat dari presentase maka dapat dikategorikan "Baik" Kualitas pelayanan publik dinilai dari cara aparatur merespon/menanggapi masyarakat dalam hal ini memberikan kepastian informasi. Hasil dari presentase tabel $71 \%$ dilihat dari presentase maka dapat dikategorikan "Baik" dinilai tentang kepercayaan kepada aparatur dalam memberikan pelayanan. Hasil presentasi $60.4 \%$ dilihat dari presentase maka dapat dikategorikan "Baik" kualitas aparatur melayani dinilai dari keramaha dalam memberikan pelayanan kepada masyarakat.

Hasil rata-rata presentase dari 5 item pertanyaan pada indikator yang berpengaruh, maka didapatkan hasil rata-rata presntase sebesar $65.8 \%$, jadi disimpulkan bahwa pada indikator ini berkategori "sering". Hasil ratarata presentase dari 5 item pertayaan pada indikator yang dipengaruhi, maka didapatkan hasil rata-rata presentase sebesar $60,32 \%$, jadi dapat di tarik kesimpulan bahwa pada indikator ini berada pada kategori "Baik".

\section{KESIMPULAN}

Berdasarkan hasil penelitian dan pembahasan yang telah diuraikan, dapat disimpulkan bahwa:

1. Berdasarkan hasil olahan analisis regresi sederhana menggunakan SPSS 16.0 for 
windows, diketahui Manajemen Perilaku Birokrasi memperoleh nilai $\mathrm{t}$ hitung $=$ 1,444 sedangkan $\mathrm{t}$ table $=0,2199$ dengan persentase $33 \%$ maka dapat dikatakan bahwa terdapat pengaruh antara Manajemen Perilaku Birokrasi terhadap Peningkatan Pelayanan Publik. Semakin baik Manajemen Perilaku Birokrasi maka akan semakin meningkat Pelayanan Publik Desa di Desa Bulo Wattang Kecamatan Panca Rijang Kabupaten Sidenreng Rappang.

2. Indikator yang paling berpengaruh dalam manajemen adalah peran pengorganisasian dan penggerakan sebesar $66,4 \%$ dan hasil terendah adalah indikator peran perencanaan dan pengawasan sebesar $65,2 \%$.

3. Adapun indikator yang paling berpengaruh dalam kualitas pelayanan publik yaitu jaminan sebesar $71 \%$ dan hasil terendah adalah bukti fisik sebesar $54 \%$, hasil tersebut dilihat berdasarkan olahan data kuisioner dan SPSS 16.0.

\section{E. REFERENSI}

\section{Buku}

Ahmad Jamaluddin.(2015). Metode Penelitian Administrasi Publik Teori dan Aplikasi. Gava Media. Yogyakarta.

Ahmad Jamaluddin.(2015). Metode Penelitian Administrasi Publik Teori dan Aplikasinya. Gama Media. Yogyakarta.

Harbani Pasolong (2014).Teori Administrasi Publik. Makassar. Alfabeta.cv

Labolo Muhadam. (2007).Memahami IImu Pemerintahan. Raja Grafindo Persada, Jakarta.

Pasolong, H. (2011). Teori Administrasi Publlik. Bandung : Alfabeta.

Sinambela, L. P. (2014). Reformasi Pelayanan Publik. Jakarta: PT. Bumi Aksara.

Sellang, K. (2016). Administrasi dan pelayanan Publik. Yogyakarta: Ombak.

Sellang, K. (2016). Administrasi dan Pelayanan Publik Antara Teori dan Aplikasi. Yogyakarta: Ombak.
Sugiyono. (2014). Metode Penelitian Kuantitatif Kualitatif dan R\&D. Bandung: Alfabeta.

Zainuddin. (2017). Teori-Teori Mutakhir dalam Perspektif IImu Administrasi Publik. Makassar: Phinatama Media.

\section{Journal}

Affandi, H., Zaki, M., Magister, M., Sipil, T., Teknik, F., Kuala, U. S., ... Kuala, U. S. (2017). Kepuasan Pelanggan pada Perusahaan Daerah Air minum (PDAM) Tirta Mon pase Kabupaten Aceh Utara. 6, 297-308.

Bawono, I. R. (2003). Manajemen Strategik Sektor Publik: Langkah Tepat Menuju Good Governance. Jurnal Fakultas Ekonomi UNSOED Purwokerto.

Eka Putra, M. I. (2016). Perilaku birokrasi pemerintah dalam pelayanan administrasi pada kantor kecamatan bontoala kota makassar.

Fadhli Muhammad, R. M. (2019). Manajemen Organisasi. In Journal of Chemical InformationandModeling(Vol.53).https://d oi.org/10.1017/CBO9781107415324.004

Juliette, N. (2015). Perilaku Birokrasi Dalam Pelayanan Publik.

Jamaluddin, Y. (2016). Model Peningkatan Kualitas Pelayanan Publik. Jurnal TAPIs, 58-61.

Punna, M. (2014). Pengaruh Kemampuan Sumber Daya Manusia Terhadap Pelayanan Publik. E-Journal.

Tulis, K., Iswanto, A. H., Kehutanan, D., Pertanian, F., \& Utara, U. S. (2008). Manajemen Pemeliharaan Mesin-Mesin.

Yuliyanti, D., \& Manusia, S. D. (2015). Pengaruh Kompetensi Sumber Daya Manusia Impor Di PT Sarana Publik Logistik Jakarta The Effect Of Competence Human Resoerces On The Quality servis Of Import Ducuments At. E-Journal, 1, 89-97.

\section{Dokumen :}

UU No 6 Tahun 2014 Tentang Desa. 
Undang-undang Republik Indonesia Nomor 15 Tahun 2014 tentang pedoman standar pelayanan.

Undang-Undang Nomor 23 Tahun 2014 Tentang Pemerintahan Daerah.

UU No. 25 Pasal 1 Tahun 2009 tentang Pelayanan Publik.

Peraturan Pemerintah nomor 2 tahun 2018 tentang standar Pelayanan Minimal. 